\title{
The rise, demise, and rebirth of a workfare programme in Israel
}

\author{
Sara Helman \\ Department of Sociology and Anthropology, Ben Gurion University of the Negev, Beersheba, Israel \\ Emal: sarith@bgu.ac.il
}

(Received 27 June 2019; revised 9 January 2020; accepted 26 June 2020)

\begin{abstract}
In this article, I present an analysis of the conditions that led to the success of an NGO coalition to challenge and bring about the suspension of a workfare program in Israel. I compare the Israeli contention against workfare with similar mobilizations that took place in France and Germany, in order to identify conditions that may enhance challenges to the politics of conditionality. I argue that the success of collective action against a workfare programme in Israel was precipitated by the formation of a loose coalition of civil society organizations which succeeded in seizing opportunities, gaining access to institutionalized political systems, and mobilizing allies from the ranks of political elites. Moreover, I demonstrate these opportunities' fluidity, such that the loss of certain allies engendered the workfare programme's rebirth. The article concludes by outlining lessons that can be learned from this case.
\end{abstract}

Keyword: unemployment; protests; neo-liberalism; Israel

During the 1990s and 2000s, welfare states promoted a new regime of conditions of eligibility for unemployment benefits and social assistance for working age individuals, based on the fulfillment of obligations (Dwyer, 2004). Paradigmatic of conditionality, workfare engenders policy changes that spur mobilization of the unemployed for collective action. Seldom have they been imposed from above without meeting resistance and contention (Baumgarten \& Lahusen, 2010; Krinsky 2008; Lahusen, 2013).

Since the 2000s, scholars have studied this mobilization of the unemployed against workfare. Most studies focus on policy-making processes, examining contentious interactions and discourses among organizations of the unemployed, trade unions, and state agencies as policy is being formulated (Baglioni, 2010). Others attend to the role of trade unions and unemployed workers' organizations in mobilizing for collective action (Chabanet, 2012). In their comprehensive analysis of the outcomes and dilemmas arising from the move towards workfare and the marketization of employment services in Europe, Greer et al. (2017, p. 172) raise the question as to how citizens may "effectively resist marketization and prevent it from taking place," but do not address it. On the whole, research has tended to overlook the process and effects of mobilization for collective action following workfare programme implementations (Krinsky, 2008; Reese, 2011). This article aims to contribute to addressing this lacuna.

Like in other nations where workfare has been introduced, in Israel protests emerged in the late 1990s and early 2000s, first in response to mass unemployment and cuts in social assistance benefits, and finally, to workfare policy proposals and implementation. However, unlike in other nations, and despite the weak political status of the long term-unemployed and the NGOs agitating on their behalf, popular protest eventually succeeded in bringing about the relatively rapid suspension of the workfare programme.

\footnotetext{
(C) The Author(s), 2020. Published by Cambridge University Press on behalf of Social Policy Association. This is an Open Access article, distributed under the terms of the Creative Commons Attribution licence (http://creativecommons.org/licenses/by/4.0/), which permits unrestricted re-use, distribution, and reproduction in any medium, provided the original work is properly cited
} 
As Reese (2011) notes, the workfare implementation process presents multiple opportunities for both supporters and opponents to debate the fate of the welfare state. In this article, I examine one such opportunity. I present an analysis of the process of a workfare programme's implementation and the conditions it created that fomented the formation of a loose coalition to agitate against the programme and successfully bring about its suspension only 5 years after its inauguration. The coalition was based on ambiguous agreements among various parties (Palier, 2005), motivated by a range of interests to oppose the workfare programme. It employed various strategies, including seizing opportunities, gaining access to institutionalized political systems, and mobilizing allies from the ranks of political elites, to ultimately bring about success in its immediate aim. However, the coalition's formation around each party's interests led to its disintegration and ultimate failure to oppose workfare once the workfare programme underwent revisions to assuage many of the demands of the various protesting parties. I argue that this case demonstrates how policy context can influence the shape of policy opposition, which in turn, when effective, can contribute to revising policy.

This Israeli case is especially worthy of attention since it showcases effective civic protest in response to neoliberal economic reform, and since Israel shares - with certain distinctions - key characteristics with conservative welfare states, such as France and Germany. Beginning in the late 1980s, like Israel, Germany, and France were beset by steadily rising unemployment figures. However, unlike in Israel, French and German pro-unemployed organizations had existed since the 1960s. In reaction to workfare policy proposals, beginning in the late 1990s, these veteran organizations succeeded in mounting massive demonstrations, yet they ultimately failed in deterring workfare's advance.

I open my analysis by giving a brief background of the scholarship of workfare implementation, focussing on the cases in France and Germany, whose comparison with the Israeli case permits me to highlight certain key factors that appear to have brought about the latter's success. Next, I present the workfare policy context in which the successful mobilization took place. Then I narrate the ways opposing coalitions emerged, garnered wide-ranging support, and succeed in bringing about workfare's suspension. Finally, I narrate the changing policy and political conditions that led to the programme's later reinstatement. I conclude by outlining lessons that can be learned from this case: (1) gradual implementation opens multiple opportunities to opponents of workfare to protest against it; (2) the outcomes of protest are contingent upon the access of the protesters to the institutionalized political systems and the mobilization of sympathetic allies from the political elites; and (3) ambiguous agreements amongst opponents of workfare are fragile, and may be affected by changing opportunities and strategic interests of the parties involved.

\section{NGOs, unions, and mobilization of the unemployed against activation and workfare}

Scholars tend to consider the unemployed, and particularly the long-term unemployed, as weak constituencies that lack resources to mobilize for collective action, generally characterizing them as isolated, heterogeneous, and stigmatized groups (Bagguley, 1991; Baglioni, 2010; Porta, 2014). However, as Tarrow (1996) notes, even the weakest and most marginalized groups can mobilize for collective action given an adequate opportunity structure, as evinced by the mobilization of the long-term unemployed in Europe since the late 1990s (Baglioni, 2010; Chabanet, 2012; Lahusen, 2013; Porta, 2014).

France, Germany, and Israel can - with some significant differences - qualify as conservative, Bismarckian welfare states (Palier, 2010). In such states, the labour market and social policy regimes contain inclusive protection for insured workers and tightly regulated labour markets, making dismissals difficult. However, since the 1990s, these states have undergone neoliberal reforms and moved away from the Bismarckian welfare state model. Significantly, they have deregulated employment, leading not only to a deepening divide between insiders and outsiders, but also to growth in the numbers of outsiders. These reforms contributed to France, Germany, and Israel experiencing successive waves of unemployment, growth in long-term unemployment, and growing numbers of social assistance recipients (Emmeneger et al., 2012).

Social assistance programmes suffer from a weak political status compared to unemployment benefits (Clegg, 2002). Given the growth of working age social assistance beneficiaries during the period under examination, and the promotion of policies to activate them, it is important to ascertain the position of unions regarding the politics of conditionality and activation as trade unions have been the historical 
advocates of social rights (Clegg, Graziano, \& van Wijnbergen, 2010). However, I maintain that it is the specific structure and the form of unions' institutional inclusion - the extent of their participation in the administration and distribution of unemployment benefits - that seems to inform their participation, or lack thereof, in coalitions that mobilize the unemployed against the politics of conditionality and workfare programmes (Baumgarten \& Lahusen, 2010).

While in France and Germany, social partners are involved in unemployment insurance through tripartite public administration or bipartite self-administration (Ebbingahus, 2010), in Israel, neither the Histadrut (General Organization of Workers) nor employers' associations are involved in the administration of unemployment benefits. We expect unions to protect its members' interests, confirmed in the Israeli case, but less so in contemporary research that presents a complicated and dynamic picture of French and German unions' stances vis-à-vis activation and non-unionized workers.

In France, due to their bipartite self-regulation (paritaire), unions first resisted the activation of the insured unemployed while supporting the activation of social assistance recipients (Classen \& Clegg, 2011, 2012). However, (Clegg, Graziano, \& van Wijnbergen, 2010) found that in the 1990s, leading French unions (especially the Confederation Francaise democratique du travail (CFDT) and Force Ouvriere (FO)) shifted their stance in favour of activation of the insured unemployed, mainly out of their interest to safely guard their prerogatives in the administrative structures of labour market policies. Along with the changing position of unions vis-à-vis activation, French unions' political fragmentation helped contribute to the emergence of autonomous organizations of the unemployed. These organizations were able in the short run to pressure governments, but their achievements were limited. Both the long-term unemployed and social assistance recipients in France remain the targets of retrenchment policies (Daguerre, 2007, pp. 111-115).

The German case witnessed a different relationship to unions. Following the Green-Red coalition's election in 1999, its initiatives to modernize the Social Democratic Party (SPD), promote the liberalization of labour markets, and revamp unemployment benefits lead to the Hartz IV reforms. Coming into effect in January 2005, this policy abolished earnings-related unemployment assistance and transferred beneficiaries to a new assistance scheme (Arbeitslogenseld II), with flat-rate, means-tested, and tax-financed benefits. The reforms were passed against the opposition of the DGB (General Confederation of Trade Unions, an umbrella organization of trade unions) in particular. The DGB especially denounced the reduction of unemployment benefits for union workers, but it was also critical of those measures that affected non-unionized workers.

Some leading members of the DGB joined a coalition of unemployed groups in the demonstrations against Hartz IV in November 2003. Then in April 2004, the DGB led massive anti-Hartz IV demonstrations. Coalitions of unions' local branches, unemployed groups, anti-globalization organizations, farleft political parties, and welfare recipients' associations demonstrated at different locales in Germany through October 2004, but the protests began to fade away upon activation's implementation in January 2005 (Baumgarten \& Lahusen, 2010). ${ }^{1}$ Not surprisingly, the support unions lent to non-union workers stemmed from their organizational interests. Benassi and Dorigatti (2015) found that leading union IG Metall perceived the Hartz IV reforms as a strategy to create a pool of cheap workers, whose availability would eventually weaken unions' bargaining power.

Across welfare states, the ambivalent or passive stance of unions vis-à-vis deteriorating benefits of the unemployed and labour market dualization that preceded the introduction of workfare programmes, created an organizational vacuum that was filled by various civil society organizations possessing resources for mobilizing the unemployed (see eg. Baglioni, 2010; Cinalli \& Gulister, 2010). In France and Germany, a dense inter-organizational field of unemployed organizations first began to grow at the local level (France in the 1980s and Germany in the 1990s), which gradually consolidated at the national level during the late 1990s, in response to the state's promotion of activation policies and the retrenchment of unemployment and social assistance benefits (Baumgarten \& Lahusen, 2010; Chabanet, 2012).

In Israel, no autonomous organizations of the unemployed emerged during the twentieth century. By the end of the 1990s, non-labour associations in civil society began to emerge, such as human rights and

${ }^{1}$ In November 2019, the Germany's high court ruled against the cuts in Harz social benefits (Motson, 2019) 
peace advocacy groups. Some of these groups began to cater to the needs and interests of discriminated groups and individuals, including temporary and foreign workers (Mundlak, 2009). Pro-unemployed NGOs only emerged in Israel following the neoliberal restructuring of the political economy by the 1990s.

\section{Neoliberal reforms in Israel and the introduction of workfare}

As in France and Germany, one of neoliberal restructuring's aims in Israel, initiated in the late 1980s and 1990s, was to replace a full employment policy with labour market flexibility (Rosenhek, 2004). To achieve it, the state scaled down the public sector, reduced financial assistance, and allowed failing businesses to close. As traditional industries (in textiles, food production, agriculture, and construction) declined, their demand for workers fell sharply.

This reduced labour demand took place amidst a massive wave of immigration from the Former Soviet Union (FSU), generating additional unemployment. Successive cycles of unemployment brought over a 100 per cent increase in the number of unemployment beneficiaries from 1989 to 2000 rates of 8.9 and 9.3 per cent, respectively), with unemployment payments growing by some 137 per cent. In 2003 , the official unemployment rate reached 10.7 per cent of the working age population, although an unofficial report claimed a high of 16.7 per cent (Anonymous, 2004)

Unskilled workers were especially affected, as they tend to experience longer unemployment spells than do other workers (Achdut, Lavih, \& Solah, 2000). Due to the limited duration of unemployment benefits, the unemployed turned to the Social Assistance Programme for relief, leading to a dramatic increase (nearly fivefold) in the number of working-age families who received social assistance benefits. Swelling unemployment figures and expenditures towards the end of the 1990s opened a window of opportunity for the Ministry of Finance to renegotiate the Israel Employment Service's (IES) form and function.

Rather than recognizing the role of neoliberal reforms and immigration, MoF senior bureaucrats interpreted the unemployment crisis and, especially, growing public expenditures, as stemming from what they viewed as the IES's incompetent and irresponsible governance. ${ }^{2}$ Despite disagreements among senior state bureaucrats over causes and solutions to the unemployment crisis, those elites promoting commodification (primarily the MoF) gained dominance and succeeded in promoting interest in the Wisconsin Works Programme (W-2), following its international acclaim for bringing about a sharp decline in the social assistance (welfare) rolls in Wisconsin in the United States (Reese, 2011, p. 12).

Once W-2 gained popularity among Israel's senior fiscal bureaucrats (for a detailed account, see author Maron and Helman 2017; Helman and Maron 2018), the Minister of Labour and Social Welfare appointed the Tamir commission to adapt and implement the programme in Israel (full name: the Commission for the Reform of the Policy toward Working-Age Recipients of Subsistence Allowances). The Tamir Commission advanced a new contract for social assistance beneficiaries, which emphasized conditioning benefits on the fulfillment of obligations, that is, conditionality (Dwyer, 2004).

The Tamir Commission recommended running four experimental programmes in four areas of the country, with each one-stop centre in each locale adhering to a different logic of action. One centre was to be operated by the Israel Employment Service (IES) (previously charged with labour market mediation), a second by a non-profit organization, a third by a for-profit organization, and a fourth through a combination of for-profit and non-profit organizations. Discontent ensued as soon as the Tamir commission published its recommendations and a coalition of NGOs, the Inter-organizational Forum against Unemployment (FOSAU), quickly formed. But unlike in Germany, where demonstrations broke out during the early stages of policy making, FOSAU only began to lobby policy actors. The NGOs composing the FOSAU came from other causes (mainly those related with the Israeli-Palestinian conflict, peace endeavors and human rights) bringing with them skills and experiences to a new urgent issue.

\footnotetext{
${ }^{2}$ For a review of similar discontent among policy makers with the functioning of PES in Germany and the ensuing change in governance, see Ebbinghaus and Eichhorst (2006); for Milwaukee, see Reese (2011, p. 83).
} 
FOSAU met with the Tamir Commission and then sent a detailed letter raising concerns regarding the programmes' compulsory character and the delegation of three of the centres to private agencies (whether non-profit or for-profit). The FOSAU demanded that as the commission prepared its final recommendations, it clarify that the proposed workfare programme cannot alone rescue an economy plagued by unemployment but would only succeed in increasing employment if additional steps were taken. FOSAU representatives further demanded that they be included in all stages of the programme's implementation (FOSAU, 2001).

While FOSAU was suspicious of the proposed workfare programme and demanded to have a monitoring role throughout its implementation, a social-democratic research centre took a stronger position, accusing the Tamir Commission of whitewashing a policy intended to erode the social safety net (Svirsky, 2001). A number of unaffiliated organizations also presented concerns to the Tamir Commission, including the Single Mothers' Forum, which sent letters to female members of parliament (henceforth MKs for members of Knesset) warning them of the backlash against single mothers. These various lobbying efforts were met by the commission with polite rejection at best, if not complete disregard.

In 2003, the proposed Mehalev programme (literally "From the Heart," an acronym for "From Welfare to Secure Employment") was legislated as an experimental programme, but not fully in line with the Tamir Commission's recommendations. Notably, the IES was excluded.

The IES union, which until the 1990s was one of the strongest public sector unions, also took a stand against the programme at its earliest stages. IES workers feared that the establishment of a new institutional layer would lead to the full privatization of labour market mediation services, thereby threatening their employment (Fox, 2017). This shift proved a crucial catalyst for the formation of a new coalition, to now include the IES workers union.

\section{Response to workfare policy: The formation and efficacy of loose protesting coalitions}

Excluding the IES, and targeting a wide range of diverse populations for participation in the Workfare Programme, including Palestinian citizens, recent immigrants from the FSU, ultra-orthodox Jews (Haredim), and other traditionally low-income communities, created a policy context that inspired a multifarious opposition. The same law that established the workfare programme, the Appropriations and Reconciliations Omnibus Law (2003-2004), also made a series of programmatic changes to the Social Assistance Programme, including adjustments to eligibility criteria and benefit rules, retrenching benefits by an average of 30 per cent. Families headed by single mothers were especially affected, immediately spurring the first wave of protests, which lasted for 3 months, assisted by various NGOs (Korazin-Koroky and Benish, 2011).

At the same time, NGOs (Commitment for Peace and Social Justice and Community Advocacy) initiated their opposition by appealing to the Supreme Court, questioning the constitutionality of the extensive cuts in social assistance benefits. According to the petitioners, the new law violated "the right of recipients of benefits to a dignified existence" (Institute, 2003). However, unlike in France, where retraction of benefits was averted through judicial appeal, (Chabanet, 2012, p. 50), in Israel the Court did not side with the litigants.

Then, in 2004, the original FOSAU resisting coalition re-assembled under the name of Mehalev Watch to monitor the programme's implementation, ensure participants' rights, and voice their expected grievances. Mehalev Watch wanted participants to become insured workers and demanded they receive training accordingly (Amzaleq et al., 2008). At this point, neither the Histadrut ${ }^{3}$ nor the IES union raised their voices against the impending implementation of the workfare programme.

\footnotetext{
${ }^{3}$ We can explain the Histadrut's indifference vis-à-vis the retrenchment of social assistance benefits and the protests that took place against the workfare programme by considering several factors. First, it has always been marginal in the administration of unemployment and social assistance benefits. Second, the decline of the Labour party, that in the past was associated with the
} 
Mehalev Watch began its work by conducting research on the outcomes of the W-2 programme as implemented in the United States. It expressed apprehension about certain differences in the Israeli version, particularly its economic incentives for private contractors to make hasty employment placements in a slow labour market with insufficient regulations: "We are afraid that the programme will turn into an assembly line of poor workers" (Benish \& Epstein, 2004; Watch, n.d.). These initial challenges served as antecedents to the contentious field that rapidly began to emerge.

Despite the political weakness of NGOs in Israel (Ben-Eliezer, 1998), a lack of support by the Histadrut, and a smear campaign against the unemployed launched by the Ministry of Finance, Mehalev Watch succeeded in seizing opportunities to reach certain policy makers and make them receptive to the claims of the unemployed. It also managed to exacerbate public debate over workfare, and most importantly, recruit the allegiance of MKs.

In August 2005, Mehalev came into effect with the establishment of four one-stop centres serving four cities and their surrounding areas in four different areas of the country (Ashkelon, Hadera, Jerusalem, and Nazareth). While in Germany protests had erupted prior to workfare's implementation, in Israel demonstrations first erupted in the different locales from the moment social assistance beneficiaries were summoned to appear, with demonstrations and marches organized by local NGOs in each of the four cities. These were spontaneous, ad-hoc demonstrations, not coordinated with Mehalev Watch.

In Nazareth, 300 people demonstrated under the slogan: "Wisconsin is a racist programme that humiliates the unemployed," implying that the workfare programme specifically targeted the already weakened economic position of Palestinian citizens of Israel. Here, local organizations - Sawt el-Amel (The Worker's Voice) ${ }^{4}$ and the Popular Committee Against the Wisconsin Programme, accompanied by an opposition MK - claimed that the programme had failed abroad and that its real purpose was to get as many people as possible off social assistance rolls, not to provide secure employment. They further emphasized that so long as the government did not generate local employment opportunities, there was no point in implementing the programme (Ashkenazy, 2005). In Ashkelon, demonstrations were organized by a local organization, programme participants, and Shatil ${ }^{5}$ (Pozner, 2006). They succeeded in mobilizing the city council to establish a local commission of inquiry (Sinai, 2005b). Large demonstrations also took place in Jerusalem and Hadera.

Seemingly aloof to the agitation, in January 2006, the Ministry of Industry, Commerce, and Employment organized a conference in Jerusalem to celebrate the first 6 months of the programme's implementation. Two demonstrations took place outside the conference venue. The Youth Caucus of the Israel Beyteinu Party ${ }^{6}$ organized a demonstration of workfare participants, largely FSU immigrants, who protested against the programme's infringement on their social rights, honor, and right to subsistence (Arutz 7, 2006). The other demonstration was the first one led by Mehalev Watch, which distributed dolls - carrying signs with messages, representing workfare recipients - to conference participants. Black balloons signifying the deleterious effects of the programme flew overhead and flyers containing demands and slogans were distributed to attendees and passersby. While workfare participants'

\footnotetext{
Histadrut. Third, the dissolution of the Ghent system (providing pensions and healthcare services to workers) brought about a sharp decline in Histadrut membership, equipping it with less resources for addressing issues outside its direct interests (Davidi, 2005; Doron, 2008; Kristal \& Cohen, 2007; Mundlak, 2009). Moreover, during the period under analysis, the Histadrut, as opposed to unions in France and Germany, concentrated on thwarting attempts to degrade the working conditions and salaries of insiders, flexibilize the labour market, and erode pensions (see Gal \& Achdut, 2007).

${ }^{4}$ Sawt el-Amal (The Worker's Voice) was founded in 1999 by workers and unemployed Palestinian citizens of Israel from Nazareth and its surrounding villages in order to support their community's poor and unemployed.

${ }^{5}$ Shatil is the operating arm of the New Israel Fund (a philanthropic organization of Israeli, European, and North American Jews). Its main purposes are to strengthen civil society organizations striving for democracy and social justice in Israel. Shatil provides capacity building and consultation services to NGOs, it engages in networking and organizing and advocacy and policy change (http://english.shatil.org.il/our-mission/).

${ }^{6}$ The Israel Beyteinu (Israel is our Home) party was founded by Avigdor Lieberman prior to elections for the 15th Knesset (1999). It appeals mainly to immigrants from the FSU. Yisrael Beyteinu presents a combination of hawkish positions in the political-security sphere alongside secular-civil positions in the religious-secular and economic divides.
} 
discontent drew public attention, advocacy NGOs' involvement in agitation played a central role in lending events greater resonance.

In contrast to workfare participants, advocacy NGOs were experienced and savvy in mobilizing the press; daily newspapers began to report the workfare participants' voicings of complaints and grievances, including the programme's failure to deliver professional training. Press reported (Ashkenazy, 2006) persons with serious disabilities were not exempted from the work eligibility test and were assigned to community service and or unhealthy work places unfitted to their age and health condition. Moreover, the press reported that case managers were rewarded for closing cases and for sanctioning participants (Grinberg \& Sinai, 2006; Rapoport, 2006; Sinai, 2005a).

In addition to giving voice to the grievances of workfare participants, Mehalev Watch also challenged the programme's basic rationality. This challenge was echoed in the Association for Civil Rights (ACRI) annual report, which lambasted the government for forsaking its responsibility towards its poorest citizens:

The declared purpose of the [workfare] program is to integrate social assistance beneficiaries into the labor market. But as stated by the government's representatives, the program's goal is to save social assistance payments. Its purpose is not to improve the participants' quality of life, but to relieve the state of its responsibility for beneficiaries' welfare. (ACRI, 2005)

Mehalev Watch's NGOs were composed mainly of middle class social democratic activists. Although workfare programme participants attended the demonstrations they organized, the compulsory character of the programme and the fear of benefit sanctions constrained their taking on bold leadership roles.

Mehalev Watch in Israel assumed a dual role throughout the period of contention. They engaged in class advocacy - disseminated research, published media commentaries, and organized protests - as well as case advocacy, conducting both in tandem. In three out of the four programme cities Hadera, Jerusalem, and Nazareth - different advocacy NGOs opened offices next to the one-stop centres and made their presence known by distributing flyers to workfare participants. Their engagement in case advocacy enabled them to become directly acquainted with the participants' tribulations and the programme's routine workings. Case advocacy also granted participants needed recognition. In contrast to pro-unemployed and welfare civil society organizations in Germany, which had professionalized as service organizations in the 1990s, ready to re-politicize in the wake of the Hartz reforms (Baumgarten \& Lahusen, 2010, p. 59-60), Israeli advocacy NGOs followed a reverse path, engaging in remedial action speedily as the result of their political action.

The Mehalev Watch NGO coalition's strategies varied according to institutional setting. Whereas on workfare hotlines and at the centres, various advocacy NGOs advised participants and mediated between them and the authorities, at parliamentary commissions and vis-à-vis the press, these same coalition sought recognition and legitimacy for participants' claims and challenged workfare's basic rationality. They employed a human rights discourse to frame their opposition and articulate the ways workfare violates social rights, as well as criticized the privatization of labour-market mediation services, the deregulated labour market, and the state's abdication of responsibility towards its poorest citizens.

Whereas in France and Germany, organizations of the unemployed lacked access to the institutionalized political system (Chabanet, 2012), in Israel Mehalev Watch lobbied MKs (members of parliament or Knesset), participated as guests at parliamentary committees deliberating on the programme, and bridged factional political gaps to succeed in generating significant political support (Amzaleq et al., 2008). Their access to elected politicians dealing with social policy was further facilitated by the lowprofile standing of social policy from among Israel's policy domains (Kriesi, 2004, p. 77), as opposed to the high profile of the national security domain and their participation as guests in parliamentary committee hearings, that granted the NGOs the opportunity to approach MKs and enlist them. The active enlistment of MKs as key allies rendered them more receptive to the claims of workfare programme participants and their civil society allies. Lobbying elected politicians belonging to both 
the ruling coalition and the parliamentary opposition proved especially strategic, as it took advantage of, and even deepened, disagreements within the ruling coalition, which bore fruit in the next elections and formation of a government.

At an urgent meeting convened in January 2006 by the Knesset State Control Committee, the ruling coalition, opposition MKs, mayors of the cities in which the programme operated, and advocacy NGOs demanded an investigation by the state comptroller (Comptroller, 2007). Lauding the NGOs foresight in reaching out to the state comptroller, one ruling coalition MK (Yuri Shtern, Israel Beytenu) notably spoke in protest against private contractors' unlimited discretion to sanction workfare participants and questioned the system's perverse reward incentives:

How can the state create a situation where the authority to deny social assistance benefits is granted to private agencies whose main purpose is to gain from the savings in allowances? Believe me, it is a lot easier to kick people off the rolls than to really assist them in finding employment. (Knesset, 2006).

While in Germany and France, minority left-leaning parties, with no political representation, supported the unemployed, in Israel, conservative right leaning parties supported by participants in the programme joined the left-wing NGOs in initiating an offensive in parliament against workfare. In Israel, the definition of left and right in politics differs from in European countries. The Israeli left-right divide refers mainly to issues of national security, not to social rights and the welfare state. Parties may hold hawkish stances regarding the Israeli-Palestinian conflict, but at the same time support expansive social policies. An alliance of strange bedfellows thus began to coalesce at this watershed meeting, where peace and social justice NGOs joined with two right-wing political parties. Two parties from the ruling coalition had constituents participating in the workfare programme, Israel Beyteinu, representing immigrants from the FSU, and Shas, ${ }^{7}$ representing ultra-orthodox Mizrahim of low socio-economic status. From the opposition, Hadash represented Palestinian citizens of Israel of low socio-economic status. These ideologically contrasting parties thus found common ground against welfare state retrenchment and workfare.

Reese notes, "If policies have inclusive targets, there are greater opportunities to build broad, influential social movement coalitions" (Reese, 2011, p. 33). Israel's workfare is a case in point: mobilization of NGOs and political parties followed from their mandates and constituencies. The inclusiveness of the workfare policy thereby catalyzed the bridging of ideological and partisan interests in generating a united opposition to workfare.

By 2007, protests, litigation, and the formation of a new governmental coalition following elections brought about the workfare programme's reorganization under a new name: Orot La'taasuka (Beacons of Employment). Under its auspices, Ely Ishay, the incoming Minister of Industry, Trade, and Employment, introduced key changes. The reward system basis for the implementing private agencies shifted to numbers of job placements from reduction of social assistance rolls, but without specifying individually tailored services. Temporary and permanent exemptions were added for certain categories of participants: people over age 45, holders of BAs and higher degrees - mainly new immigrants from the former Soviet Union and Torah students - and the disabled (Anonymous, 2007). The exceptions clearly targeted the constituents of Israel Beyteinu and Shas (Ishay's political party). Ishay then declared that the programme would be expanded to two new locales.

The programme's reorganization opened a new window of opportunity for its opponents. In 2008, a reorganized coalition of NGOs headed by Rabbis for Human Rights ${ }^{8}$ (henceforth RHR coalition) responded to recommendations issued by an academic-public commission monitoring the programme,

\footnotetext{
${ }^{7}$ Shas is a religious party in Israel. Founded in 1984 under the leadership of Rabbi Ovadia Yosef, it primarily represents the interests of ultra-Orthodox Mizrahi Jews.

${ }^{8}$ Including Rabbis for Human Rights, the Mizrahi Democratic Rainbow, Singur Kehilati, Ma'an, and the Alternative Information Centre. The re-organized coalition expanded to include Ma'an and the Alternative Information Centre voicing the grievances of the Palestinian citizens of Israel and Palestinian inhabitants of East Jerusalem participating in the workfare
} 
which had endorsed the changes introduced by Minister Ishay, called for the programme's continuation and expansion, and reiterated its underlying logics. The coalition challenged the programme's rationality and its construction of the target population as job snobs and scroungers, advancing an alternative framing of the problem in a pamphlet:

We do not agree that the long-term unemployed do not want to work. ${ }^{9}$ We maintain that the problem is utterly different. The problem stems from the structure of the labor market and the educational, training, and transportation systems. The program does not provide answers to these problems. Activating the unemployed through sanctions-instead of creating jobs, raising the minimum wage, enforcing labor legislation, and improving education-is a war against the poor and not a war against poverty. (Tanami, 2008)

In the same pamphlet, the RHR coalition proposed alternatives to the workfare programme, emphasizing the state's responsibility to create decent jobs, education, and training for the unemployed, as well as to strictly enforce labour protections, especially for those at the lower rungs of the labour market.

Although the programme's reorganization was expected to mollify protest against the programme, especially among members of the Welfare, Labour and Health Commission of the Knesset, mobilization in fact expanded, since the changes were only cosmetic without altering the programme's underlying rationale. By this time, thanks to the programme's gradual and experimental implementation, the partnership among the RHR coalition, the MKs, and IES union grew stronger (Mandelkern \& Koreh, 2018).

In 2008, the Knesset voted to extend the experimental programme for 2 years (through the Omnibus Law), in spite of strong opposition, while the MoF drafted plans to expand it to the national level with the establishment of one-stop centres in 30 areas to be run by 6 for-profit and non-profit organizations. The programme's proposed national implementation was to require participation with no exceptions by all working-age social assistance beneficiaries (Dinur, 2007; Sinai, 2008a). Minister Ishay opposed this nationwide expansion in the absence of a comprehensive programme to fight poverty, as well as its outsourcing to private contractors, instead proposing that the IES play a role in implementation (Peled, 2008). The IES and its union were also adamantly opposed to the expansion unless it administered the programme (Peled, 2008; Sinai, 2008b). Moreover, the IES workers' union claimed time and again that they could perform the work of integrating social assistance beneficiaries into the work force, should the MoF allocate them the necessary resources (Knesset, 2009). NGOs, the ruling coalition, and opposition members of the Knesset Finance Committee and Labour, Social Welfare, and Health Commission also opposed it on this and other grounds.

A new window of opportunity for challengers opened in 2009 , as the initial law launching the programme approached expiration. The governing coalition decided to exclude the programme's expansion from the Omnibus Law (Lavie, 2009; Zarhia, 2009), thus requiring the drafting of two bills for consideration before the full Knesset, one approving the programme's nation-wide implementation and the other proposing expansion to only two more cities.

As the time to vote on the bills approached, the RHR coalition disseminated a booklet in the Knesset (RHR, DMR, \& ACRI, 2009), challenging multiple aspects of the proposals. At the end of April 2010, the

programme. Rabbis for Human Rights voiced the grievances of Israeli Jewish and Palestinians. Commitment for Peace and Justice dropped from the coalition.

${ }^{9}$ The NGOs coalition sought to destigmatize the long-term unemployed, and, capitalizing on the centrality of work, offered an alternative explanation for the causes of long-term unemployment and poverty. Whereas the fiscal bureaucracy attributed poverty to individual factors such as lack of motivation to work and to dependence in social benefits, workfare opponents attributed it to structural forces. As the workfare program was a "work first program," it did not provide the participants with professional training. Emulating W-2, if participants attended activities, they were generally no more than classes in motivation and soft skills. Moreover, transportation and child care issues were especially acute for Arab participants, due to the lack of child care centers (Almagor-Lotan, 2008; Shatawi \& Forum, 2010) and poor public transportation in Arab towns and villages. 
Labour, Social Welfare, and Health Commission held heated deliberations over the bills. In a climate of mounting opposition and with the publication of an analysis by the Legal Aid Department of the Ministry of Justice noting the programme's faults and abuses, the Labour, Social Welfare, and Health Commission of the Knesset rejected both bills, effectively suspending the programme (Lavie, 2010; Zarhia, 2010).

\section{Workfare's revision and reinstatement}

Despite the programme's abrupt termination, efforts to reinstate workfare persisted. The Ministry of Finance prepared new initiatives and struggled to restore workfare as the dominant policy logic of its labour and social policy regime. In May 2013, following a newly formed government, the MoF brought to the Knesset a proposal to renew the programme, this time at the national level. Learning from previous experiences and in order to avoid protest and opposition, the MoF proposed to operate the programme under the auspices of the IES. This was the most fundamental change introduced to the proposal (for similar processes in Europe, see Greer et al., 2017). The Knesset approved the proposal, establishing a new programme, Ma'agaley Hataasuka (Circles of Employment), at nine branches of the IES. Then in 2014, the MoF attempted to expand the programme nationally using temporary employees rather than IES staff members. Naturally, the IES workers' union opposed it and the expansion was stalled. In 2016, an agreement with the IES union enabled the programme's expansion. The agreement regulated the relations between the external providers (mainly coachers and instructors in the different workshops provided by the programme) and the IES's employees (for details on the agreement see Adut, 2017). By the end of that year, it reached implementation in 26 IES branches, with plans to continue nationwide expansion and uphold it as the central programme of labour market and social policy (Adut, 2017). While some attempts were made by RHR and ACRI to mobilize opinion against this latest iteration of the programme (Lev, 2014; ACRI, 2014), they failed to spur collective action.

The programme's reformulation as a public project within the IES eliminated opposition by elected politicians and the IES union. The IES attained its main objective, administering the programme, and therefore, they had no reason to protest against or to oppose it. Not only did the MoF include the IES to mollify it, but it made sure that to address other concerns such as: (1) targeting social assistance recipients closer to the labour market (as opposed to inclusion of the hard to place in Mehalev/Orot Ha'taasuka). (2) Elimination of economic incentives for the reduction of social assistance rolls and fast placements in the labour market. (3) Making the participation in the programme voluntary at first. (4) Withholding the authority of coachers to sanction beneficiaries. Circles of Employment is still a work-first programme, but less demanding than the previous Mehalev and Orot La'Taasuka.

Since the agitating NGOs and the IES workers' union opposition to the workfare programme was based on ambiguous agreement, once the IES succeeded in administering the programme, the coalition lost most of its partners and power, and former allies among the political elites, the IES union, and the press expressed no discontent with the new programme (Frankel, 2019; Lavie, 2017).

Alongside the compulsory Circles of Employment programme administered by the IES, the Ministry of Labour, Welfare and Social Services encourages participation in voluntary employment programmes for special groups (youth at risk; ultra-orthodox men and women; Arab women; Ethiopian new immigrants; and persons with disabilities) run by NGOs. Similarly to France's insertion initiatives (Schulte et al., 2018) where there is leeway for local, decentralized initiatives that challenge the state's workfare logics, the voluntary programmes in Israel, while being subsidized by the state, are not one-sizefits-all programmes, and their underlying rationale is to adapt to the different target groups' needs. ${ }^{10}$

Has the conflict over the fate of Israel's state welfare state been settled? While between 2004 and 2010, re-commodifiers and de-commodifiers each tried to advance their logics and position, in the end, since

\footnotetext{
${ }^{10}$ https://www.molsa.gov.il/employment/welfarepopulationsemployment/employmentprograms/Pages/ EmploymentPrograms.aspx
} 
2014, positions became renegotiated and a common ground was established whereby both sides could have some of their goals. The MoF neoliberal reformers got workfare, albeit in a milder form that they initially sought. The IES got to not only keep its position, but expand their roles and ranks. The long term unemployed got a less punitive programme, although their salaries do not seem to have improved (Adut, 2017; Schlosser \& Shannan, 2018).

\section{Concluding remarks}

The promotion of the politics of conditionality represented a path breaking change in contemporary welfare states. These policy changes, that conditioned the eligibility for unemployment and social assistance benefits on the fulfillment of obligations, engendered debates over the fate of the welfare state, between de-commodifiers and re-commodifiers, and spurred contention and resistance.

While the promotion of workfare, as paradigmatic of the politics of conditionality spurred protest, the mobilization for collective action occurred at different stages of the policy-making process. Moreover, the outcomes of collective action against workfare were contingent upon the specificities of national institutions and politics.

The comparison of protests against workfare programmes in three Bismarckian welfare states Germany, Israel and France - permits demarcation of conditions that may explain different outcomes of these challenges.

A first lesson that can be learned from the analysis of the Israeli case is that the process of implementation and especially gradual implementation provides multiple windows of opportunity for opponents of workfare to form loose coalitions of resistance, that gather momentum at the different stages of implementation, and to bring about the interruption of workfare programmes. While in Germany massive opposition took place during the initial stages of policy making, and faded after the implementation of Harziv, Israel exhibits a different trajectory. Protest and contention were initiated in Israel during the process of implementation, lead by small and weak NGOs that sought to give voice to the grievances of the programme's participants. While the IES union did not participate in the protests, nor was part of the NGOs coalition, it opposed to the workfare programme fearing that its implementation would threaten their employment and perhaps even lead to its obsolescence. Thus, an ambiguous agreement-based on different reasons and interests to oppose the workfare programme emerged.

However, another condition was pivotal for the ambiguous agreement to bring about policy change. This a second and fundamental lesson that can be gained from the Israeli case and that determined the outcomes of the mobilization against workfare. Reese (2011, pp. 32-33) claims that "poor peoples' mobilization tends to be the most successful in winning benefits when [...] government allies are present." The Israeli case shows that critical to the outcomes of mobilization, was the capacity of NGOs to take advantage of the political climate in Israel, where programme's participants had representatives in the ruling coalition. Moreover, the NGOs coalitions were able to bridge across deeply ingrained ideological divisions between right and left, and between coalition partners and the opposition, thereby strengthening the opposition to the workfare programme and eventually bringing about its interruption.

However, cooperation among NGOs, unions, and political elites may be temporary and fragile, especially if these coalitions are based on ambiguous agreement. Given the different interests and reasons underpinning the ambiguous agreement, these coalitions will tend to lose their power, once a key party succeeds in gaining some achievements. Unions either mobilize against or support activation, depending on their strategic interests. Governments promoting workfare programmes may succeed in co-opting members of the challengers' coalition, as was the case when the Israeli government co-opted the IES by awarding it implementation of the programme, thereby mollifying the opposition of MKs and the IES union and weakening the NGO coalition. RHR coalition ultimately found itself alone in challenging the programme.

In sum, the Israeli case shows that the implementation stage of workfare programmes creates opportunities for mobilization against them (Reese, 2011). However, mobilization outcomes are not 
only contingent upon the existence of a wide network of pro-unemployed organizations, but also upon challengers' access to the institutionalized political system and possibilities for capitalizing on discontents and controversies over the fate of the welfare state amongst elected politicians. Finally, it is important to recognize that alliances among resisters are invariably fragile, affected by changing opportunities and strategic interests of the actors involved.

Disclosure statement. No potential conflict of interest was reported by the author.

Notes on contributors. Sara Helman is Associate Professor at the Department of Sociology and Anthropology - Ben Gurion University of the Negev. Her research fields are the sociology of citizenship, social movements, and identity, welfare state configuration with special emphasis on workfare programmes. She has published in various journals such as the British Journal of Sociology, Constellations, Journal of Social Policy and Social Politics. http://coolcite.com/user/1541\#Personal.

\section{References}

Achdut, L., Lavih, V., \& Solah, V. (2000). Unemployment in Israel during the last decade - Trends, characteristics and changing patterns. Economic Quarterly, 47(3), 303-343.

ACRI. (2005). Human rights in Israel. Jerusalem: ACRI.

ACRI. (2014). The circles of employment program may curtail the beneficiaries' rights. Jerusalem, ACRI

Adut, R. (2017). Circles of employment and outsourcing: Analysis and recommendations. Jerusalem Van Leer Institute.

Almagor-Lotan, O. (2008). Child care services in the Arab Sector. Jerusalem

Amzaleq, N., Epstein, B., Gross, T., Maimon, O., \& Rei, G. (2008). Monintoring as an instrument for social change: The case of Mehalev watch. Jerusalem Knesset Research and Information Center.

Anonymous. (2004). The real unemployment rate: 16.7 percent. YNET. Retrieved from https://www.ynet.co.il/Ext/Comp/ ArticleLayout/CdaArticlePrintPreview/0,2506,L-2872452,00.html accessed 24/8/2018

Anonymous. (2007). The government decided that the Wisconsin program will be from now on called: Beacons of Employment Globes accessed 24/08/2018.

Ashkenazy, E. (2005). A demonstration in Nazareth against the Wisconsin program: A racist program. Haaretz. Retrieved August 25, 2005, from http://news.walla.co.il/item/768435

Ashkenazy, E. (2006). The Israel Employment Service exempted them from work; the Wisconsin program thought otherwise. Haaretz.

Bagguley, P. (1991). From protest to acquiescence?: political movements of the unemployed. London: Macmillan Education.

Baglioni, S. (2010). The role of civil society actors in the contentious politics of unemployment. In M. Giugni (Ed.), The contentious politics of unemployment in Europe: Welfare states and political opportunities (pp. 127-151). New York: Palgrave-Macmillan.

Baumgarten, B., \& Lahusen, C. (2010). The Mobilization of the Unemployed in Germany (1198-2004). In D. Chabanet, Fanie\& Jean (Eds.), The Mobilization of the Unemployed in Europe (pp. 57-88). New York: Palgrave-Macmillan.

Ben-Eliezer, U. (1998). State versus civil society? A non-binary model of domination through the example of Israel. Journal of Historical Sociology, 11(3), 370-396.

Benassi, C., \& Dorigatti, L. (2015). Straight to the core-Explaining union responses to the casualization of work: The IG M et al campaign for agency workers. British Journal of Industrial Relations, 53(3), 533-555.

Benish, A., \& Epstein, B. (2004). An assembly line of poor workers. Haaretz.

Chabanet, D. (2012). The long history of a new cause: The mobilization of the unemployed in France. In D. Chabanet \& J. Faniel (Eds.), The mobilization of the unemployed in Europe (pp. 29-56). New York: Palgrave Macmillan.

Cinalli, M., \& Gulister, K. (2010). Networks and political contention over unemployment: A comparison of Britain, Germany and Switzerland. In M. Giugni (Ed.), The contentious politics of unemployment in Europe: Welfare states and political opportunities (pp. 70-93). New York: Palgrave-Macmillan.

Classen, J., \& Clegg, D. (2011). Unemployment protection and labor market change in Europe: Towards a triple integration? In J. Classen \& D. Clegg (Eds.), Regulating the risks of unemployment: National adaptations to post-industrial labor markets in Europe (pp. 1-12). New York: Oxford University Press.

Classen, J., \& Clegg, D. (2012). Adapting labour market policy to a transformed employment structure: The politics of triple integration. In G. Bonoli \& D. Natali (Eds.), The politics of the new welfare state (pp. 135-158). Oxford: Oxford University Press.

Clegg, D. (2002). The political status of social assistance benefits in European welfare states: Lessons from reforms to provision for the unemployed in France and Great Britain. European Journal of Social Security, 4(3), 201-226. doi:10.1023/a: 1021376819763 Retrieved from https://journals.sagepub.com/doi/abs/10.1023/A\%3A1021376819763 
Clegg, D., Graziano, P., \& van Wijnbergen, C. (2010). Between sectionalism and revitalisation: Trade unions and activation policies in Europe. REC-WP Working Papers on the Reconciliation of Work and Welfare in Europe (07-2010).

Comptroller, S. (2007). Some aspects of the Mehalev program (Wisconsin program). Jerusalem: S. Comptroller.

Daguerre, A. (2007). Testing resistance to change: The erratic imposition of workfare at the margins of french society active labour market policies and welfare reform: Europe and the US in Comparative Perspective (pp. 105-129). London: Palgrave Macmillan.

Davidi, E. (2005). The Histadrut in Reccess: Who supports workers' struggles?

Dinur, R. A. (2007). Report of review commission of the "Welfare to Employment Program". Jerusalem: Government of Israel.

Doron, A. (2008). Unemployment in Israel in the 21st Century: Why is there no unemployment movement? Iyunim Betkumat Israel, 18, 125-151.

Dwyer, P. (2004). Creeping conditionality in the UK: From welfare rights to conditional entitlements? Canadian Journal of Sociology, 29(2), 265-287.

Ebbingahus, B. (2010). Reforming Bismarckian corporatism: The changing role of social partnerships. In A long goodbye to Bismarck - The politics of welfare reform in continental Europe (pp. 255-278). Amsterdam: Amsterdam University Press.

Ebbinghaus, B., \& Eichhorst, W.. (2006). Employment regulation and labor market policy in Germany, 1991-2005. IZA Discussion Paper No. 2505.

Emmeneger, P., Hausermann, S., Palier, B., \& Seeleib-Kaiser, M. (2012). How we grow unequal. In P. Emmeneger, S. Hausermann, B. Palier \& M. Seeleib-Kaiser (Eds.), The age of dualization: The changing face of inequality in deinsdustrializing socieities (pp. 3-26). Oxford: Oxford University Press.

FOSAU. (2001). Reform for the treatment of the unemployed: The demands of the Interorganizational Forum Against Unemployment. Letter.

Fox, J. (2017). Outsourcing manpower: The case of the Israel Employment Service. Jerusalem: MA. Hebrew University of Jerusalem.

Frankel, B. (2019). The program for the integration of social assistance claimants and recipients expands. YNET.

Gal, J., \& Achdut, N. (2007). A safety net full of holes: Changing policy towards Israel's social assistance program. In U. Aviram, J. Gal, \& J. Katan (Eds.), Formulating social policy in Israel. Jerusalem: Taub Center for Social Policy Studies in Israel.

Greer, I., Breidahl, K. N., Knuth, M., \& Larsen, F. (2017). The marketization of employment services: The dilemmas of Europe's work-first welfare states Oxford: Oxford University Press.

Grinberg, M., \& Sinai, R. (2006). Wisconsin program operators force unemployed people to work without pay at IDF bases in the territories as a "contribution to the community." Haaretz.

Helman, S. and A. Maron. (2019). Episodes of Translation and Network Resilience: Lessons from Israel's attempted institiuionalization of workfare. Journal of Social Policy 48,1:63-82

Institute. (2003). Appeal N\# 336/03 against the cuts in social assistance benefits. Jerusalem: Mechuyavut Le'Shalom uleTzedek Hevrati.

Knesset. (2006). Minutes of the State Control Committee. Jerusalem: Knesset, Government of Israel.

Knesset. (2009). The integration of working age social assistance beneficiaries into employment. Commission for Work, Welfare and Health, Protocol 170.

Korazin-Koroky, Y., \& Benish, A. (2011). The governance of protest: Vikky Knafo and the single mothers' protest in Israel. Jerusalem: Jerusalem Papers for the Study of Governance and Regulation.

Kriesi, H. (2004). Political context and opportunity. In The Blackwell companion to social movements, pp. 67-90. David A. Snow, Sarah H. Soule and Hanspeter Kriesi (eds) Malden. MA, Blackwell Publishers

Krinsky, J. (2008). Free labor: Workfare and the contested language of neoliberalism Chicago: University of Chicago Press.

Kristal, T., \& Cohen, Y. (2007). Decentralization of collective agreements and rising wage inequality in Israel. Industrial Relations: A Journal of Economy and Society, 46(3), 613-635.

Lahusen, C. (2013). The protests of the unemployed in France, Germany and Sweden (1994-2004): Protest dynamics and political contexts. Social Movement Studies, 12(1), 1-22. doi:10.1080/14742837.2012.723369

Lavie, T. (2017). Circles of employment - A success. YNET.

Lavie, Z. (2009). The bill for the expansion of the Wisconsin program was excluded from the Omnibus Law. YNET.

Lavie, Z. (2010). The end of the Wisconsin program. YNET. Retrieved August 24, 2019, from http://www.ynet.co.il/articles/ 0,7340,L-3882129,00.html.

Lev, I. (2014). The Circles of Employment Program: to exhaust you until you are discouraged for applying to social assistance benefits. http://rhr.org.il/heb/2014/01/15597 (last accessed 24/08/2019)

Mandelkern, R., \& Koreh, M. (2018). Interrupting gradual institutional change: How 'continuity agents' have stalled and even reversed gradual welfare-state reforms in Israel. Journal of European Public Policy, 25(11), 1706-1725.

A. Maron and S. Helman. (2017). Unraveling the Politics of Activation Reforms: exploring the unusual Israeli case. Social Policy and Administration 51, 3:405-423

Motson, N. (2019). In Brief: Germany's high court rules: Large cuts to Hartz iv social benefits are unconstitutional.

Mundlak, G. (2009). Addressing the legitimacy gap in the Israeli corporatist revival. British Journal of Industrial Relations, 47(4), 765-787. 
Palier, B. (2005). Ambiguous agreement, cumulative change: French Social Policy in the 1990s. In W. Streeck \& K. Thelen (Eds.), Beyond continuity: Institutional change in advanced political economies (pp. 127-144). Oxford: Oxford University Press.

Palier, B. (2010). Ordering change: Understanding 'Bismarckian' welfare states reform trajectory. In B. Palier (Ed.), A long goodbye to Bismarck? The politics of welfare reform in continental Europe (pp. 19-44). Amsterdam: Amsterdam University Press.

Peled, M. (2008). The Minister of Trade, Industry and Employment opposes the Ministry of Finances plan to the nation-wide expansion of the Wisconsin Program. Calcalist.

Porta, D. D. (2014). The protest on unemployment. In M. Giugni (Ed.), The contentious politics of unemployment in Europe: Welfare states and political opportunities (pp. 43-69). New York: Palgrave-Macmillan.

Pozner, S. (2006). A demonstration against the Wisconsin program, today in Ashkelon. News1.

Rapoport, M. (2006). Behind the optimistic data presented by the promoters of the Wisconsin program. The Marker.

Reese, E. (2011). They say cutback, we say fight back!: Welfare activism in an era of retrenchment New York: Russell Sage Foundation.

RHR, DMR, \& ACRI. (2009). No, Mr Minister. Jerusalem: Maspik.com.

Rosenhek, Z. (2004). Globalization, domestic politics and the restructuring of the welfare state. In E. Benvenisti \& G. Nolte (Eds.), The Welfare State, Globalization and International Law (pp. 79-101). Berlin: Springer.

Schlosser, A., \& Shannan, Y. (2018). Evaluation report on employment circles program. Tel Aviv.

Schulte, L., Greer, I., Umney, C., Symon, G., \& Iankova, K. (2018). Insertion as an alternative to workfare: Active labourmarket schemes in the Parisian suburbs. Journal of European Social Policy, 28(4), 326-341.

Shatawi, U., \& Forum, W. S. B. (2010). Lack of child care centers as the main barrier to Arab women's employment. Tel Aviv.

Sinai, R. (2005a). $80 \%$ of the participants in the Wisconsin program in Hadera want to get a medical exemption. Haaretz.

Sinai, R. (2005b). A municipal committee will examine the complaints of Ashkelon inhabitants against the Wisconsin Plan. The Marker.

Sinai, R. (2008a). A commission recommends to include one hundred thousand persons in the workfare program. Haaretz.

Sinai, R. (2008b). Director General of the Israel Employment Service: I will block the nation-wide expansion of the Wisconsin Program. Haaretz.

Svirsky, B. (2001). Comments on the Tamir Commission's Report. Tel Aviv: A. Center.

Tanami, N. G. (2008). An alternative proposal to the faults of the Wisconsin program. JerusalemRabbis for Human Rights and ACRI.

Tarrow, S. (1996). States and Opportunities: the political structuring of social movements, pp. 41-61 in: D. McAdam, J. McCarthy and Meyer Zald (eds) Comparative Pespectives on Social Movements. Cambridge, Cambridge University Press

Watch, M. (n.d.). The Wisconsin program - From welfare to what kind of employment? In Jerusalem, Mehalev Watch

Zarhia, Z. (2009). A compromise between Netanyahu and Shas: The expansion of the Wisconsin program will not be included in the Omnibus Law. The Marker.

Zarhia, Z. (2010). The Wisconsin program in danger: It might be suspended in a fortnight. Haaretz.

Cite this article: Helman, S. (2021). The rise, demise, and rebirth of a workfare programme in Israel. Journal of International and Comparative Social Policy 37: 62-75. https://doi.org/10.1017/ics.2020.18 